\title{
Article \\ Circular Economy for Municipal Solid Waste Incineration Bottom Ash (MSWIBA) Management in Mortars with CSA and CEM I, MSWIBA Glassy Phase, and DTG
}

\author{
Nikolina Poranek ${ }^{1,2,3, *(D)}$, Beata Łaźniewska-Piekarczyk ${ }^{2}$ (D) Adrian Czajkowski ${ }^{3,4,5, * \mathbb{D}}$ and Krzysztof Pikoń ${ }^{1}$ \\ 1 Department of Technologies and Installations for Waste Management, Faculty of Energy and Environmental \\ Engineering, The Silesian University of Technology, Konarskiego 18, 44-100 Gliwice, Poland; \\ krzysztof.pikon@polsl.pl \\ 2 Department of Building Engineering and Building Physics, Faculty of Civil Engineering, The Silesian \\ University of Technology, Akademicka 5, 44-100 Gliwice, Poland; Beata.Lazniewska-Piekarczyk@polsl.pl \\ 3 Doctoral School, The Silesian University of Technology, Akademicka 2A, 44-100 Gliwice, Poland \\ 4 EnergySol s.c., Przepiórek 53, 43-100 Tychy, Poland \\ 5 Department of Power Engineering and Turbomachinery, Faculty of Energy and Environmental Engineering, \\ The Silesian University of Technology, Konarskiego 18, 44-100 Gliwice, Poland \\ * Correspondence: nikolina.poranek@polsl.pl (N.P.); adrian.czajkowski@polsl.pl (A.C.)
}

check for

updates

Citation: Poranek, N.;

Łaźniewska-Piekarczyk, B.;

Czajkowski, A.; Pikoń, K. Circular Economy for Municipal Solid Waste Incineration Bottom Ash (MSWIBA) Management in Mortars with CSA and CEM I, MSWIBA Glassy Phase, and DTG. Energies 2022, 15, 135.

https://doi.org/10.3390/en15010135 Academic Editors: Gheorghe Voicu and Gigel Paraschiv

Received: 1 December 2021

Accepted: 22 December 2021

Published: 25 December 2021

Publisher's Note: MDPI stays neutral with regard to jurisdictional claims in published maps and institutional affiliations.

Copyright: (C) 2021 by the authors. Licensee MDPI, Basel, Switzerland. This article is an open access article distributed under the terms and conditions of the Creative Commons Attribution (CC BY) license (https:// creativecommons.org/licenses/by/ $4.0 /)$.

\begin{abstract}
The increase in frequency and intensity of natural disasters is related to the changing global average temperature. Reducing greenhouse gas emissions and the extraction of natural resources is one of the solutions proposed by the European Green Deal and the 17 Sustainable Development Goals (SDGs) approved by the United Nations. The article presents research on municipal solid waste incineration bottom ash (MSWIBA), which is the basis for its circulation in the idea of the circular economy. The MSWIBA study presents differential thermogravimetry (DTG), glassy phase, and mortars using CSA and CEM I. The management of MSWIBA contributes to reducing greenhouse gas emissions and the extraction of natural resources.
\end{abstract}

Keywords: bottom ash; secondary waste; municipal solid waste incineration plant; global warming; CSA; Portland cement (CEM I 42.5 R); glassy phase; differential thermogravimetry (DTG); European Green Deal; Sustainable Development Goals; cement production

\section{Introduction}

\subsection{Natural Disaster, European Green Deal, and Sustainable Development Goals}

Progressive global warming and climate change are causing environmental degradation. Species extinction, melting of glaciers, and increased frequency and intensity of natural disasters are some of the effects of rising temperatures. Global economic and population growth is increasing exposure to these risks [1-3]. This means that human and material losses are proportional to environmental degradation. Table 1 shows selected major natural disasters in terms of resources lost between 1997 and 2017 [4].

The largest losses were recorded in 2017 in the USA, following Hurricanes Harvey, Irma, and Maria and the resulting floods, which amounted to USD 221 billion. Biodiversity losses, soil depletion, and ocean floor depletion are hard to quantify, but their degradation will have unspecified consequences in the future.

Stopping the temperature increase by up to $2{ }^{\circ} \mathrm{C}$ offers an opportunity to avoid dangerous tipping points in the climate system, as established by the UN Framework Convention on Climate Change. COP26, held in Glasgow in 2021, thoroughly discussed climate change and its impact for the globe, especially for developed countries. At the climate summit, the parties reviewed the commitments under the 2015 Paris Agreement, which marked the way forward in climate action [2]. The European Green Deal also highlights the problem of global warming and aims to achieve zero net greenhouse gas emissions by 2050 [5]. Figure 1 shows selected environmental and climate preventures. 
Table 1. Selected largest natural disasters in terms of lost resources in 1997-2017.

\begin{tabular}{cccc}
\hline Place & Kind of Catastrophe & Year & The Amount of Loss, USD bn \\
\hline USA & Drought & 2012 & 26.7 \\
USA & Tornado and storms & 2011 & 14.2 \\
USA & Hurricane IKE & 2008 & 41.8 \\
USA & Hurricane Katrina & 2005 & 157 \\
USA & Hurricane Sandy & 2012 & 73 \\
USA & Hurricane Andrew & 1992 & 26.5 \\
USA & Hurricanes Harvey, Irma, and Maria & 2017 & 221 \\
Europe & and resulting floods & 2003 & 17.2 \\
Europe & Heat waves and droughts & 1997 & 10.7 \\
Pakistan & flood & 2010 & 12.1 \\
China & floods and landslides & 2016 & 24.5 \\
Thailand & floods & 2011 & 41.3 \\
\hline
\end{tabular}

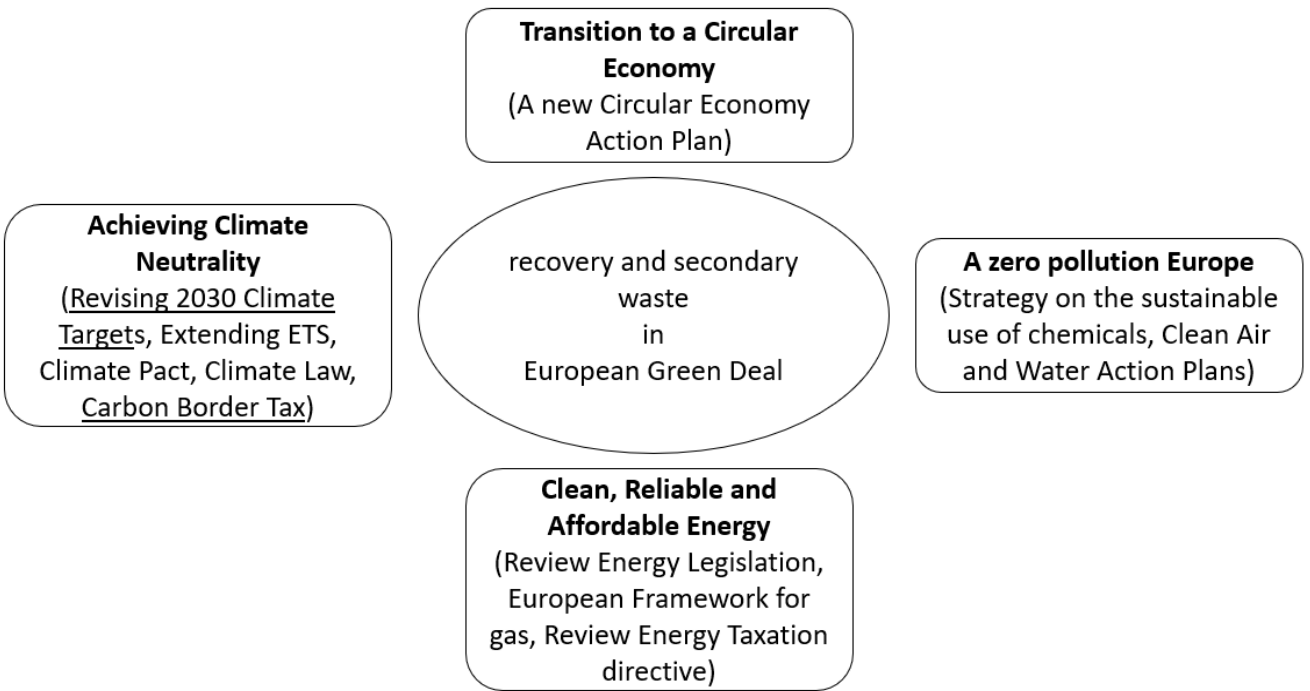

Figure 1. Selected European Green Deal projects that include climate and environmental protection.

Currently, the efficiency of the gas cleaning installation is very high, and the biggest problem is the secondary waste. Figure 2 shows the CE scheme and the place of recovery if the secondary waste was managed. The whole would then fall into the 3 Rs (ReduceReuse-Recycle) [3].

By managing secondary waste and following the CE concept, the environmental footprint is reduced, generating increased income and reducing resource dependency [6].

However, there are calculating that despite climate policy introduction, reducing $\mathrm{CO}_{2}$ emissions will reduce the temperature in 2100 by only $0.17^{\circ} \mathrm{C}$. Hence, some climate simulations indicate the influence of anthropogenic pollution on the increase of the global temperature but to a small extent [7].

\subsection{Incineration Plant}

Figure 2 shows a waste incineration plant as part of the circular economy when secondary waste is recycled. Waste incineration plants are a necessary part of the waste management system because not all waste can be recycled. Some of the contaminated, oily, mixed, and residual waste is not suitable for reuse or the production of alternative fuel. The only possibility for energy recovery is thermal treatment in a waste incineration plant. A waste incineration plant is divided into the following: 
- Delivery of waste. In this area, the waste is checked for radioactivity, weighed, and unloaded into a bunker. The hall is under negative pressure, which prevents odors from escaping to the outside.

- Burning and recovery. In this zone, the waste is thermally treated on a furnace, which is fed by a crane. The combustion temperature is approximately $850^{\circ} \mathrm{C}$.

- Flue gas treatment. In this zone, the waste gas is purified by a bag filter. The treated waste gases and emissions are released into the atmosphere via the chimney.

- Recovery. In this zone, thermal energy is recovered, which is then transformed by the turbine into electricity. Depending on the needs of the city or the plant, the energy is transferred accordingly.

\section{REDUCE \\ ENVIRONMENTAL \\ FOOTPRINT}

GENERATE

INCREASED

INCOME

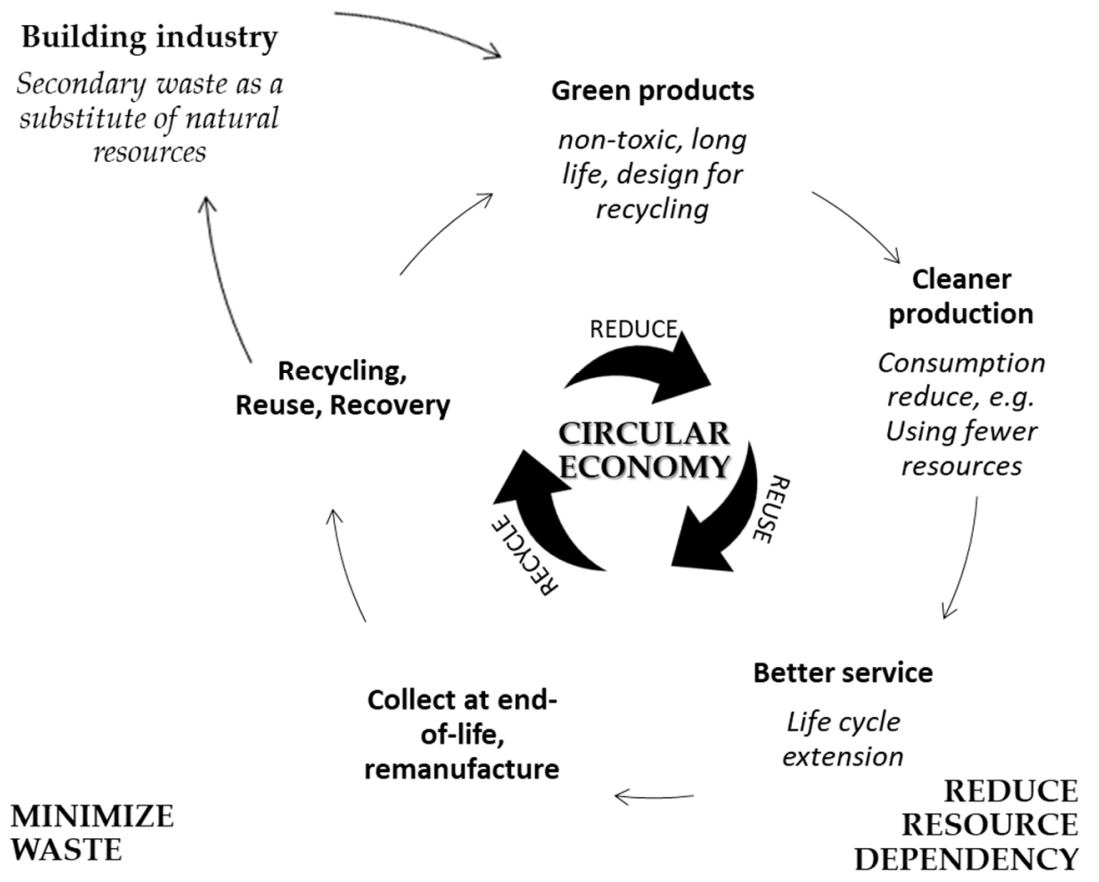

Figure 2. Secondary waste in the circular economy.

Secondary waste. In this zone, the waste generated during the process is collected. MSWIBA (19 01 12-European Waste Catalogue number) is collected, which is then subjected to a valorization process, which is described in detail in [8]. Fly ash (19 $0107^{*}$ European Waste Catalogue number, the "**" means hazardous waste) is loaded into barrels and taken to the site where it undergoes the stabilization/solidification (s/s) process and is then stored in the form of monoliths. Boiler ash is a waste product, which, depending on the installation, is, e.g., added to fly ash and disposed of together with it $[8,9]$. Figure 3 shows the incineration plant scheme with treatment zones [10].

During the process, approximately $30 \%$ of MSWIBA is produced from incinerated municipal waste. The amount of MSWIBA can vary depending on the morphology of the municipal waste, such as the content of inorganic substances, glass, porcelain, or metals. The greater the proportion of incombustible compounds, the greater the amount of MSWIBA [11].

Some European Union countries are saturated with incineration plants, which cover the demand for the management of the combustible fraction. Such countries include, for example, Germany and France. Some countries are struggling with insufficient capacity. In Poland, for example, there is a lack of infrastructure for the management of combustible 
waste. The collection of combustible waste by incineration plants in Poland is comparable to the capacity of cement plants.

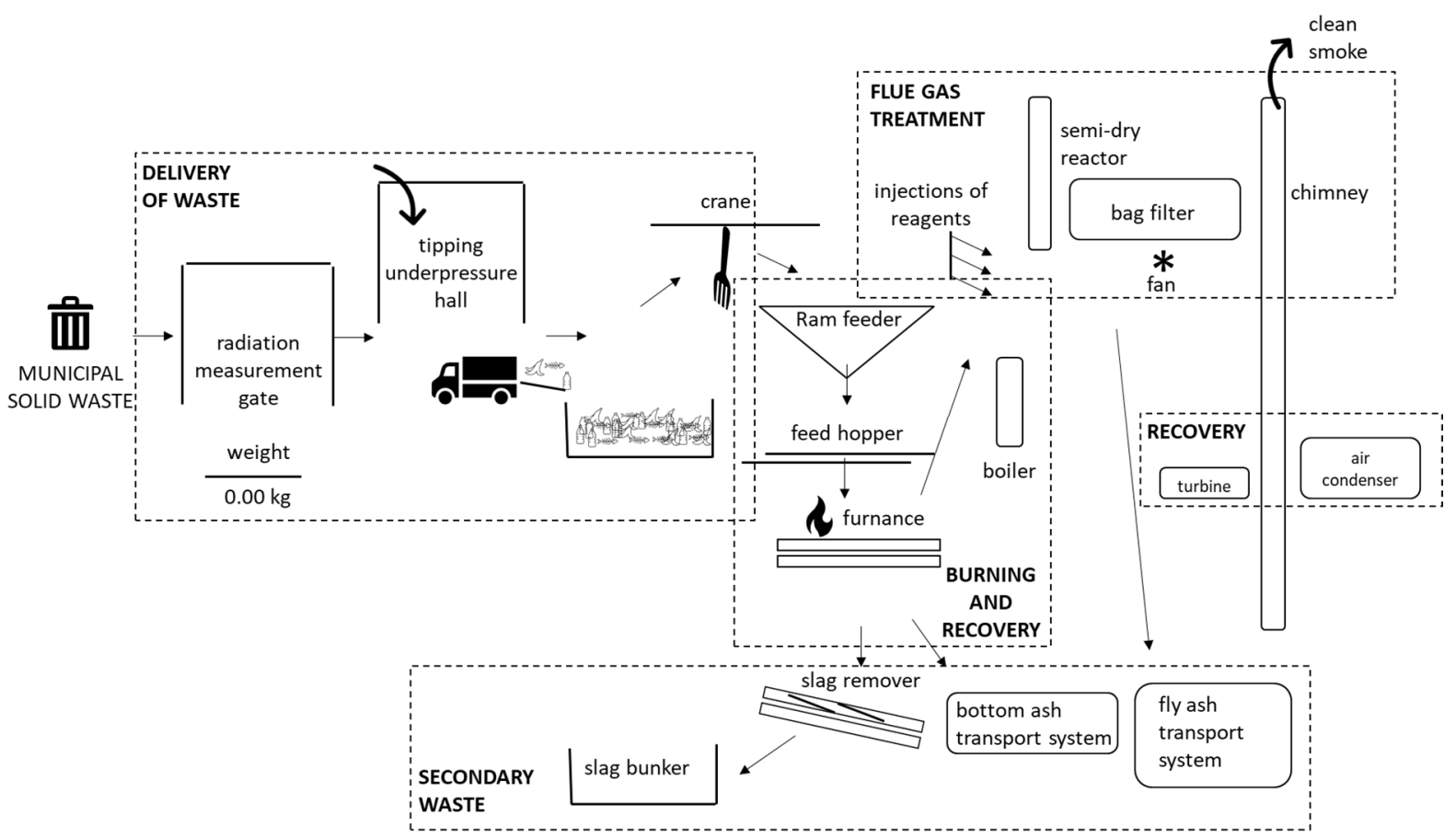

Figure 3. Incineration plant.

Table 2 shows the number of installations and the processing capacity of incineration plans in the selected countries.

The highest number of WtE plants is in France (126) with a capacity of 14.4 million Mg per year, while the highest capacity is in Germany (26.8 million Mg per year) with 96 installations. Estonia, Lithuania, and Luxembourg each have one WtE plant. In total, 98 million $\mathrm{Mg}$ of waste is treated at 492 incineration plants in Europe per year, of which about 30 million $\mathrm{Mg}$ of secondary waste is generated.

Coarse aggregate in concrete represents approximately $42 \%$ of the mix volume, while fine aggregate represents $28 \%$ of the max volume. If all 190112 aggregate is substituted, it can account for $70 \%$ of the volume of concrete. The range of fractions of 190112 after the valorization process is $0-150 \mathrm{~mm}$.

Secondary waste from incineration plants can be managed in pasty filling in underground mining or as aggregate additive in road priming.

\subsection{MSWIBA Manage in Construction}

The building sector is a high emitting sector of the economy. Construction in Europe is responsible for almost $50 \%$ of all natural resources used, $40 \%$ of energy consumption, $35 \%$ of greenhouse gas emissions, $33 \%$ of all waste produced, and 30\% of water consumption [12,13].

Cement is the basic binder used in construction. The process of making cement is an energy-intensive and carbon-intensive process. The production of $1 \mathrm{Mg}$ of cement uses about $1 \mathrm{Mg}$ of raw minerals and emits almost $1 \mathrm{Mg}$ of $\mathrm{CO}_{2}$. Cement production accounts for $5-10 \%$ of total anthropogenic emissions of carbon dioxide in the world. The amount of $\mathrm{CO}_{2}$ emissions results from the calcination of carbonate minerals $(60 \%)$ and the combustion of fuels $(40 \%)[14,15]$. 
Table 2. Number of WtE plants operating in Europe (not including hazardous waste incineration plants) and waste thermally treated, $\operatorname{mln} \mathrm{Mg}$ w 2017.

\begin{tabular}{|c|c|c|c|c|c|c|c|c|c|c|c|c|c|c|c|c|c|c|c|c|c|c|}
\hline & \begin{tabular}{l} 
ते \\
\multirow{2}{0}{} \\
Z
\end{tabular} & 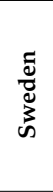 & 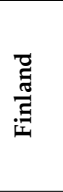 & 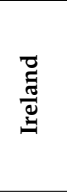 & 光 & 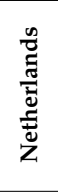 & 志 & 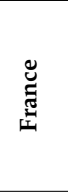 & 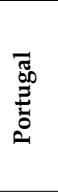 & $\begin{array}{l}\text { ॠू } \\
\text { के }\end{array}$ & $\stackrel{ }{\overparen{\Xi}}$ & 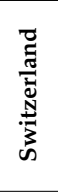 & 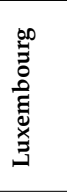 & $\frac{\pi}{\underline{Z}}$ & 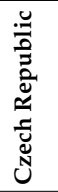 & 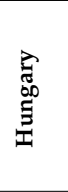 & $\begin{array}{l}\frac{\pi}{3} \\
\frac{\pi}{\tilde{\sigma}} \\
\frac{0}{\omega}\end{array}$ & 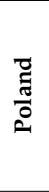 & 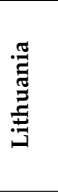 & 营 & 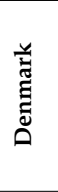 & 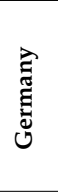 \\
\hline $\begin{array}{l}\text { WtE Plants operating } \\
\text { in Europe }\end{array}$ & 18 & 34 & 9 & 2 & 40 & 12 & 17 & 126 & 4 & 12 & 39 & 30 & 1 & 11 & 4 & 1 & 2 & 6 & 1 & 1 & 26 & 96 \\
\hline $\begin{array}{l}\text { Waste thermally threated, } \\
\mathrm{mln} \mathrm{Mg}\end{array}$ & 1.63 & 6.1 & 1.61 & 0.48 & 10.9 & 7.6 & 3.4 & 14.4 & 1.2 & 3 & 6.11 & 6.11 & 0.17 & 2.6 & 0.7 & 0.35 & 0.23 & 0.8 & 0.25 & 0.22 & 3.4 & 26.8 \\
\hline
\end{tabular}

To reduce greenhouse gas emissions from the construction sector, the use of concrete, steel, and cement, among other things, can be reduced. The European Environmental Agency has announced the potential to reduce greenhouse gas emissions by $61 \%$ by 2050 , compared to 2015. The report "Cutting greenhouse gas emissions through circular economy actions in the buildings sector" presents opportunities to reduce emissions from the buildings sector [1]. The key circular economy actions are product design, production process, demolition, waste management, and consumption models [1].

The result of the MSWIBA Life Cycle Assessment shows savings in $\mathrm{CO}_{2}$ equivalent and fossil depletion per $1 \mathrm{~kg}$ of different kinds of cement. For example, in the case of the Portland cement substitution, approximately $1.35 \mathrm{~kg}$ equivalent per $1 \mathrm{~kg}$ and $0.1 \mathrm{~kg}$ fossil depletion were saved. The full LCA analysis is presented elsewhere $[8,16,17]$.

Figure 4 shows the two loops of the circular economy process, where the key points of $\mathrm{CO}_{2}$ emissions and natural resource consumption are marked in red. In green (with "-") are marked key points of raw materials and $\mathrm{CO}_{2}$ emissions saved.

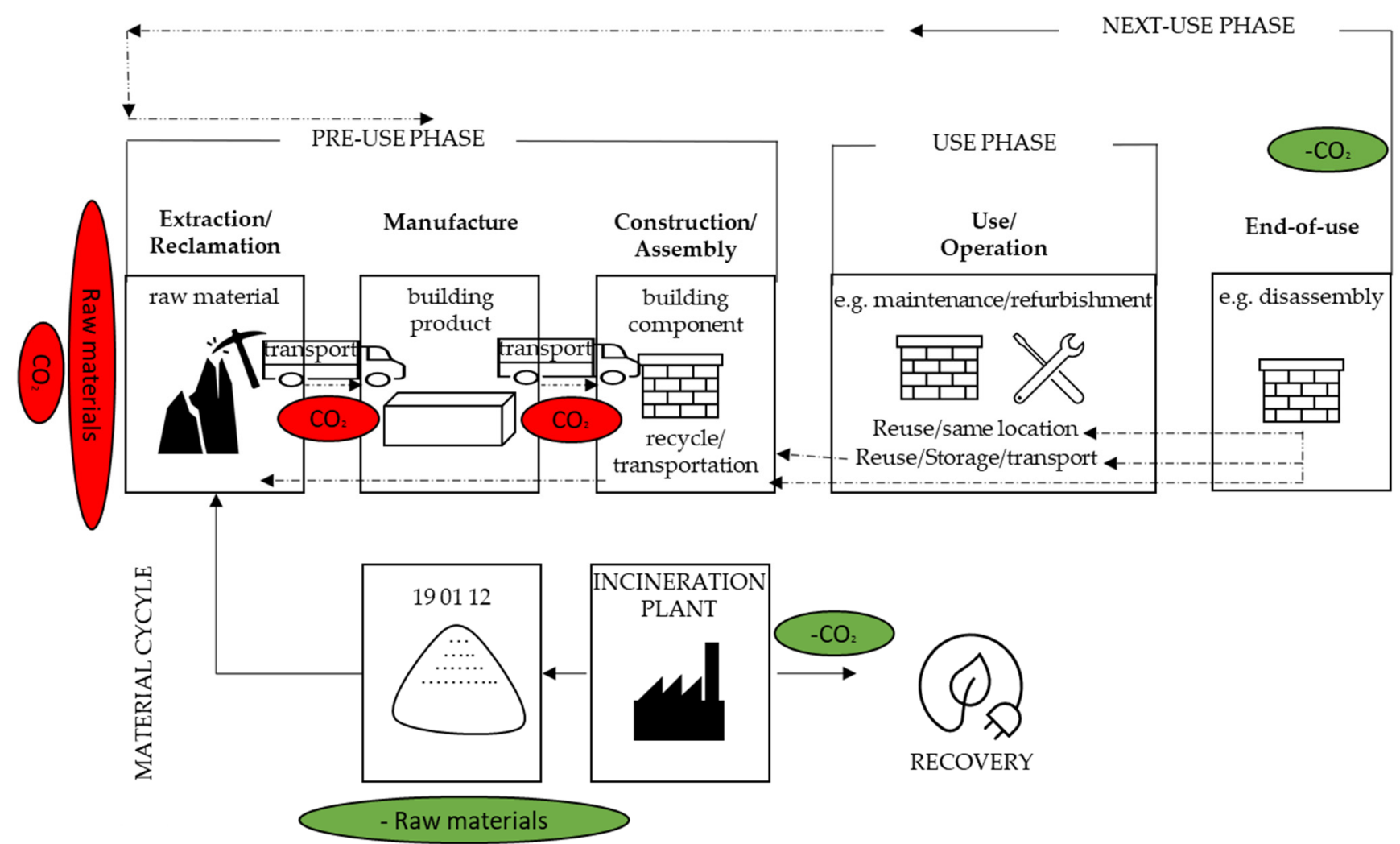

Figure 4. Circular economy of 190112 and old buildings materials. $\mathrm{CO}_{2}$ savings and $\mathrm{CO}_{2}$ emissions during the material cycle and circular economy process. 
Figure 4 shows a loop in which energy was recovered from waste and secondary waste went to the construction industry. The second loop shows the use of the movement of material produced using 1901 12. The implementation of 190112 in the construction industry will further extend the life of the material due to the properties of supplementary cementing materials, which are described in Section 2.1.

\section{Materials and Methods}

\subsection{Bottom Ash}

Bottom ash has the code 190112 (bottom ash and slag other than those mentioned in 1901 11). The test sample is the $0-8 \mathrm{~mm}$ fraction. The waste is grey. It is not dusty or dirty. It has no characteristic odor. The figure shows the tested bottom ash [8]. Figure 5 represents MSWIBA.

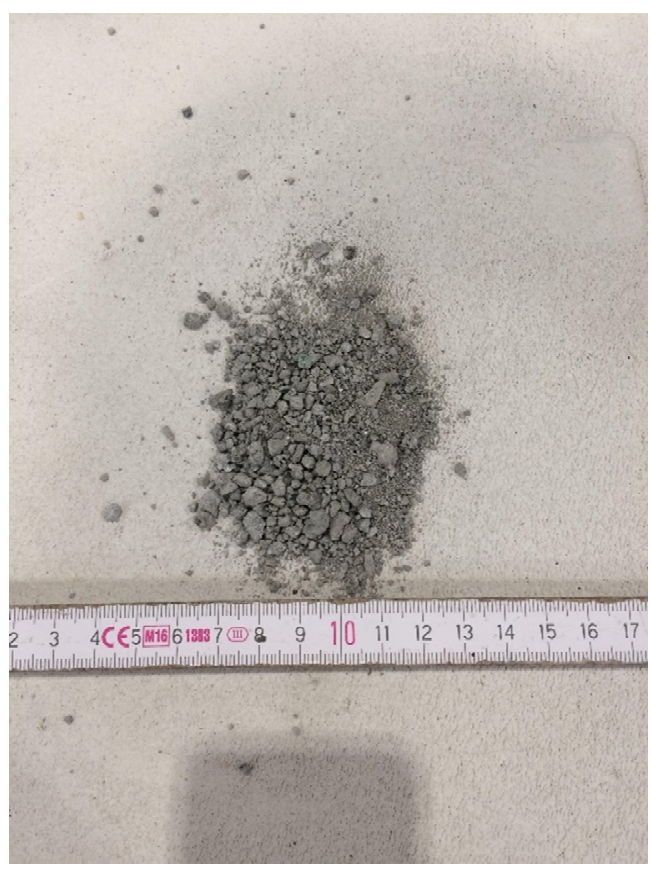

Figure 5. MSWIBA.

MSWIBA is a porous aggregate. Glass and porcelain can be seen in the MSWIBA sintering [17].

The literature analysis indicates the pozzolanic properties of MSWIBA. The pozzolanic material, i.e., "a siliceous and aluminous material which, in itself, possesses little or no cementitious value but which will, in finely divided form in the presence of moisture, react chemically with calcium hydroxide at ordinary temperature to form compounds possessing cementitious properties". The intensity of the pozzolanic reaction properties may vary with each batch of material due to the heterogeneity of MSWIBA. The properties of MSWIBA depend on the combustion process and the fraction processed. For example, the amount of organic carbon depends on the time and temperature at which the municipal waste is incinerated. Sulfur, heavy metals, and chlorine depend on the chemical properties of the municipal waste [18].

The intensity of the pozzolanic reaction properties may vary with each batch of material due to the heterogeneity of MSWIBA. The properties of MSIBA depend on the combustion process and the fraction processed. For example, the amount of organic carbon depends on the time and temperature at which the municipal waste is incinerated. Sulfur, heavy metals, and chlorine depend on the chemical properties of the municipal waste [18].

Currently, SCMs are pulverized fly ash (PFA), round granulated blast furnace slags (GGBFS), and silica fume (SF). However, due to the Paris Agreement, countries will move 
away from coal-fired power generation. Hence, the number of SCMs currently in use will decrease. Therefore, to fill the future market gap, substitutes such as 190112 should be introduced, especially since the amount of waste is not decreasing despite the introduction of a waste hierarchy [18].

\subsection{CSA and Portland Cement Mortars}

Portland cement is a mineral hydraulic binder. The raw materials for clinker production are limestone, marl limestone, marl, and clay. The firing temperature of the raw materials reaches $1450{ }^{\circ} \mathrm{C}$. The flame and gas temperatures are about $2000{ }^{\circ} \mathrm{C}$. The material in the high-temperature zone stays for about $0.5 \mathrm{~h}$. High temperatures make the clinker firing process an energy- and emission-intensive process. In addition, natural resources are consumed in cement production [19-21]. Figure 6 shows the production of Portland cement.

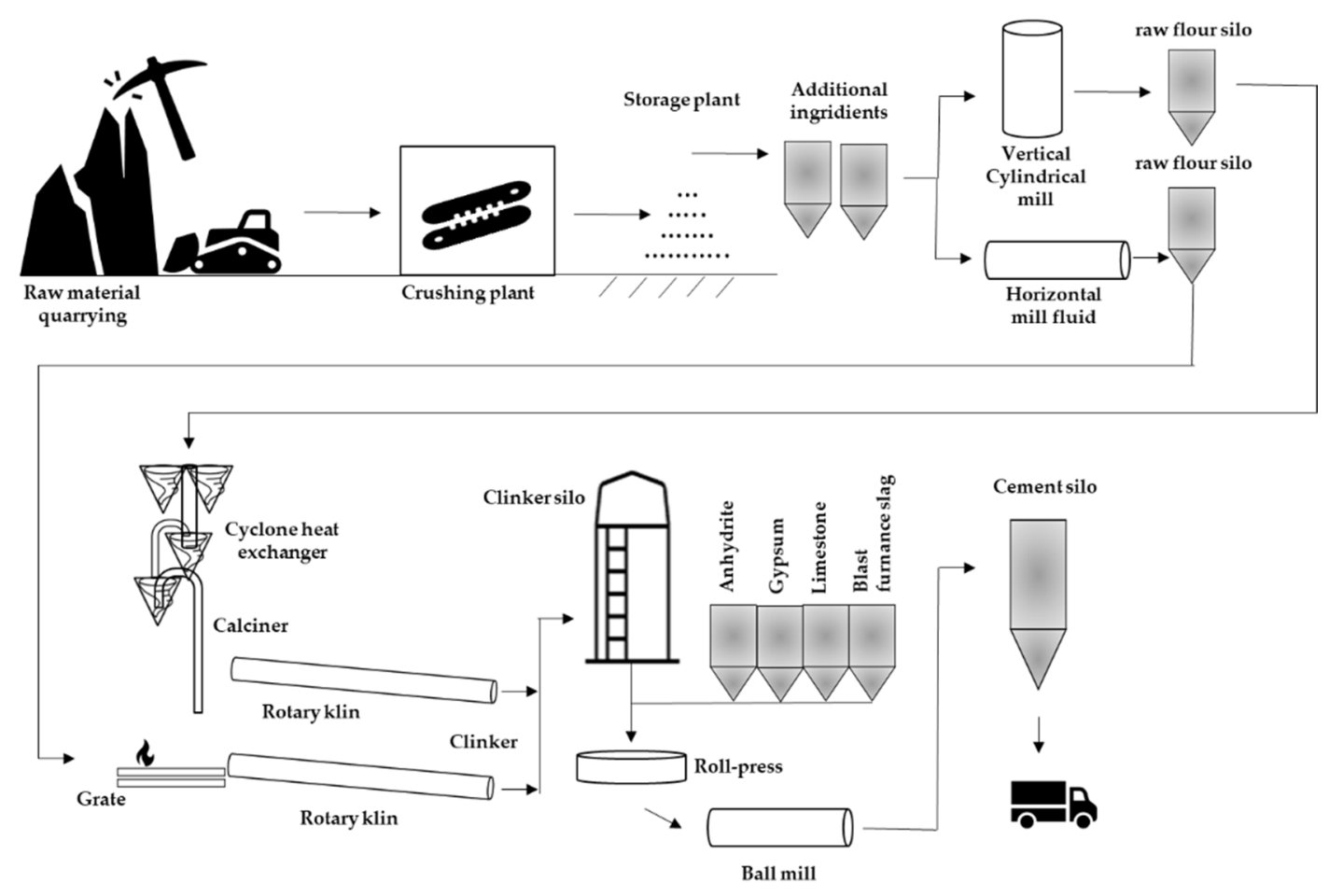

Figure 6. Portland clinker and cement production.

Calcium Sulfoalumine Cement (CSA) is a mineral hydraulic binder. CSA is formed after the milling of sulphate clinker and calcium sulphate. The main constituent is $\left(\mathrm{Ca}_{4}\left(\mathrm{AlO}_{2}\right) 6 \mathrm{SO}_{4} / \mathrm{C}_{4} \mathrm{~A}_{3} \mathrm{~S}\right)$ [22]. Figure 7 shows clinker and CSA production scheme.

The raw materials for the production of CSA cement are limestone, bauxite, and gypsum. The firing temperature is about $1250{ }^{\circ} \mathrm{C}$, which is about $200{ }^{\circ} \mathrm{C}$ lower than that of Portland clinker. This results in higher carbon and energy intensity of the CSA production process [22].

Portland cement and CSA differ in composition. This results in different hydration processes [22]. In both CSA and Portland cement production, recycled raw materials, i.e., alternative fuels, can be used. However, the average $\mathrm{CO}_{2}$ emissions from the production of CSA cement are much lower at $599 \mathrm{~kg} \mathrm{CO} 2 \mathrm{eq} / \mathrm{Mg}$. The average $\mathrm{CO}_{2}$ emission from the production of Portland cement CEM I is $798 \mathrm{~kg} \mathrm{CO}$ eq $/ \mathrm{Mg}$ [22].

This work aims to research MSWIBA in terms of management in the building industry. The importance of this work is environmentally and economically beneficial. The conducted tests allow us to learn about the physicochemical properties of MSWIBA and compare them with other materials used in construction. Thanks to the research, it will be possible to select MSWIBA more precisely as a substitute in specific concrete mixtures. 


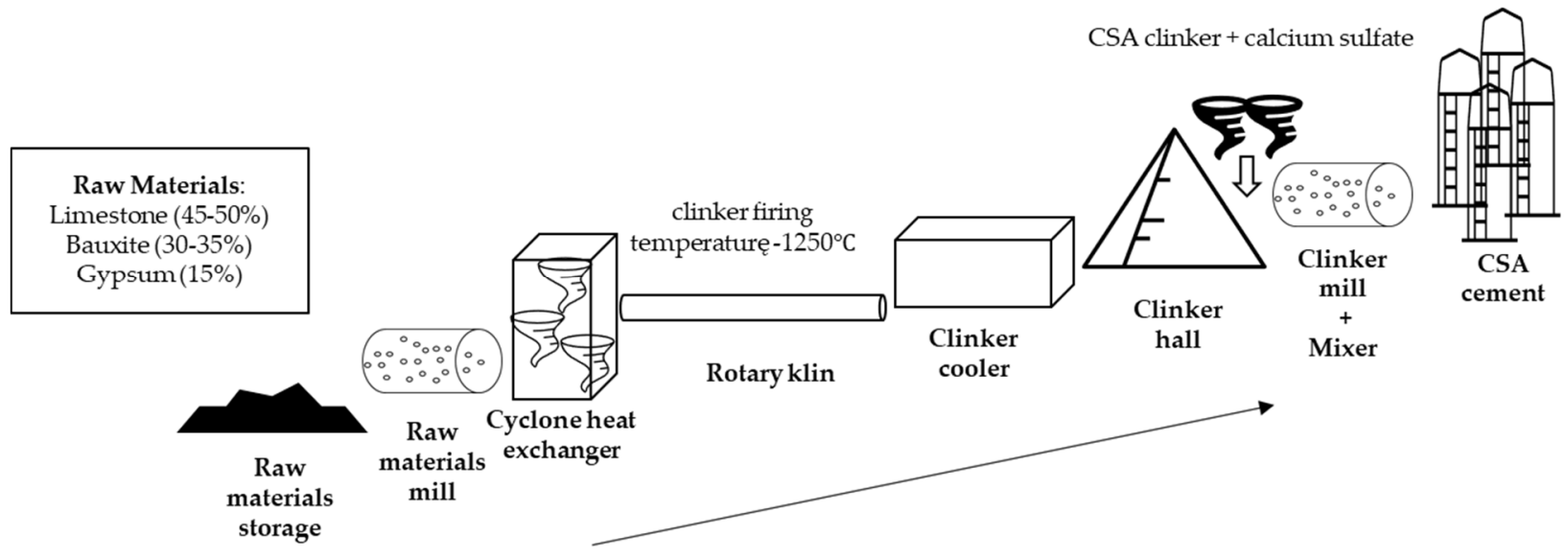

Figure 7. Clinker and CSA production scheme.

An important aspect is also the use of various types of cement in mixtures. By comparing CSA and CEM I 42.5R, a better cement can be selected from an environmental and economic point of view in construction mixture with MSWIBA.

\subsection{MSWIBA Analysis and Tests}

The purpose of the research and tests carried out is to determine the physicochemical properties of MSWIBA. Selected studies were carried out in terms of the development of MSWIBA in construction.

Sieve analysis is one of the methods of granulometric analysis that determines the fractional composition of a material. Sieve analysis was performed using a set of sieves with different mesh diameters. The analysis was performed using the dry method. Analysis was performed in accordance with the PN-EN 933-1 standard.

During the TG analysis, changes in the mass of the test material during heating are recorded. The analysis is recorded with the TG curve, according to the Formula (1):

$$
\Delta m=\int(t)=\int(T)
$$

The differential thermogravimetric curve (DTG) is obtained by re-estimation of the rate of mass change $(\mathrm{dm} / \mathrm{dt})$, according to the Formula (2):

$$
\mathrm{dm} / \mathrm{dt}=\int(t)=\int(T)
$$

DTG analysis was performed in the temperature range $25-1600{ }^{\circ} \mathrm{C}$ in an air atmosphere. Losses of mass for the analyzed samples were determined, and the onset, endset, and peak were determined on the DTG curve [23].

Mass losses were determined for MSWIBA. The temperatures of the beginning (onset), the end (endset), and the maximum intensity of the transformation (peak) were determined on the DTG curves.

The test was performed in accordance with the INS/IChN-IA/GS/09 procedure "Thermal analysis". The test was performed using a thermobalance: TGA/DSC 3+ prod. Mettler-Toledo (Switzerland).

Glassy phase is built like crystalline silica, but it is amorphous (has no ordered internal structure).

Amorphous (glassy) phase occurs as separate elements of the microstructure or is located at grain boundaries. Phase identification by X-ray diffraction was performed according to PN-EN 13925-1: 2007 and PN-EN 13925-2: 2004 standards. Quantitative phase composition by X-ray diffraction was performed according to PN-EN 13925-1: 2007 standard. 
Strength tests were performed by producing $4 \times 4 \times 16 \mathrm{~cm}$ blocks. The blocks, after removal from the molds, were kept in an aqueous environment for 28 days. The mortars were then placed in a testing machine on two supports, where the strength was tested by destroying them. The strength test was carried out according to the PN EN 196-1 standard. The device is designed for strength tests of masonry mortars, plasters, floor screeds, floors, cement, etc. The test stand (by controls) allowed us to determine the bending strength of a $40 \times 40 \times 160 \mathrm{~mm}$ beam and to determine the compressive strength of a $40 \times 40 \times 40 \mathrm{~mm}$ sample.

The press met the requirements of the EN 196-1: 2005 standard. The stand can enable tests according to the following standards: PN-EN 12004 (method described in PN-EN 1348: 1999); PN-EN 998-1 (method described in PN-EN 1015-12: 2002); PN-EN 998-2 (method described in PN-EN 1015-12: 2002); PN-90/B-14501 (method according to PN85/B-04500); PN-B-30042: 1997 (method according to PN-86/B-04360); and PN-EN 13813 (method according to PN-EN 13892-8: 2004) [24].

The leachability test was performed by shaking the samples in distilled water for $24 \mathrm{~h}$ in a closed, dark container. The extract was filtered through a soft filter. The $\mathrm{pH}$ of the extract and the aqueous extract were performed according to the standard PN-EN ISO 10523:2012.

\section{Results}

\subsection{MSWIBA Sieve Analysis}

Sieve analysis was carried out to determine the grain size of fractions. The factors influencing the choice of grain size are aggregate surface area, the relative volume occupied by the aggregate, workability of the mixture, and segregation tendencies. The MSWIBA sieve analysis is presented in Table 3.

Table 3. MSWIBA sieve analysis.

\begin{tabular}{|c|c|c|c|c|c|c|c|c|}
\hline \multirow{3}{*}{ Fraction } & \multirow{3}{*}{$\begin{array}{c}\text { Mesh } \\
\text { Sieve Size } \\
{[\mathrm{mm}]}\end{array}$} & \multicolumn{5}{|c|}{ Overflow Fraction } & \multicolumn{2}{|c|}{ Subsieve Fraction } \\
\hline & & \multirow{2}{*}{ I Sample } & \multirow{2}{*}{ II Sample } & \multirow{2}{*}{ III Sample } & \multicolumn{2}{|c|}{ Average } & \multirow{2}{*}{$\begin{array}{c}\text { Mesh Sieve } \\
\text { Size }[\mathrm{mm}]\end{array}$} & \multirow{2}{*}{ Summary [\%] } \\
\hline & & & & & g & $\%$ & & \\
\hline $0-0.063$ & 0 & 0.8 & 1.4 & 1.9 & 1.37 & 0.05 & 0.063 & 0.05 \\
\hline $0.063-0.125$ & 0.063 & 13.5 & 23.4 & 23.8 & 20.2 & 0.67 & 0.125 & 0.72 \\
\hline $0.125-0.25$ & 0.125 & 91.2 & 115.3 & 116.3 & 107.6 & 3.59 & 0.25 & 4.31 \\
\hline $0.25-0.5$ & 0.25 & 389.4 & 348.1 & 406.0 & 381.2 & 12.71 & 0.5 & 17.01 \\
\hline $0.5-1$ & 0.5 & 607.1 & 409.4 & 497.7 & 504.7 & 16.82 & 1 & 33.84 \\
\hline $1-2$ & 1 & 571.3 & 479.1 & 551.4 & 533.93 & 17.80 & 2 & 51.63444 \\
\hline $2-4$ & 2 & 764.4 & 888.0 & 823.1 & 825.2 & 27.51 & 4 & 79.14 \\
\hline $4-8$ & 4 & 547.9 & 722.2 & 569.9 & 613.3 & 20.44 & 8 & 99.58 \\
\hline $8-16$ & 8 & 14.4 & 13.1 & 9.9 & 12.5 & 0.42 & 16 & 100.00 \\
\hline $16-32$ & 16 & 0.0 & 0.0 & 0.0 & 0.0 & 0.00 & 32 & 100.00 \\
\hline
\end{tabular}

The sand point was $51 \%$. The fines fraction (oversize) was $0.42 \%$, which confirmed that the tested MSWIBA fraction is $0-8 \mathrm{~mm}$. Based on the sieve analysis, it was concluded that MSWIBA can be used as an aggregate replacement. However, the aggregate grain was round, while MSWIBA has a larger specific surface area [25].

In further studies, it is necessary to select the rest of the aggregate to be used in concrete based on sieve analysis. The selection of a coarse fraction alone (e.g., basalt) will lower the sand point, so when making a ready-mix concrete aggregate with MSWIBA, a certain amount of sand should also be added. It will also be necessary to test the concrete because of the potential for unpredictability in the workability of the mix due to the previously mentioned different specific surface areas of the MSWIBA grains [25].

\subsection{TG and DTG Analysis}

The results of the DTG MSWIBA analysis are shown in the Table 4 and Figure 8. 
Table 4. Onset, peak, endset and weight loss of MSWIBA in DTG analysis.

\begin{tabular}{ccccc}
\hline Temperature Range & Onset $\left[{ }^{\circ} \mathbf{C}\right]$ & Peak $\left[{ }^{\circ} \mathrm{C}\right]$ & Endset $\left[{ }^{\circ} \mathbf{C}\right]$ & Weight Loss [\%] \\
\hline $25-150{ }^{\circ} \mathrm{C}$ & 53.0 & 72.1 & 91.9 & 4.61 \\
$100-150{ }^{\circ} \mathrm{C}$ & 108.1 & 122.43 & 152.4 & 0.58 \\
$500-700{ }^{\circ} \mathrm{C}$ & 588.49 & 635.4 & 667.2 & 1.72 \\
$1000-1300^{\circ} \mathrm{C}$ & 1011.5 & 1134.3 & 1223.2 & 1.09 \\
\hline
\end{tabular}

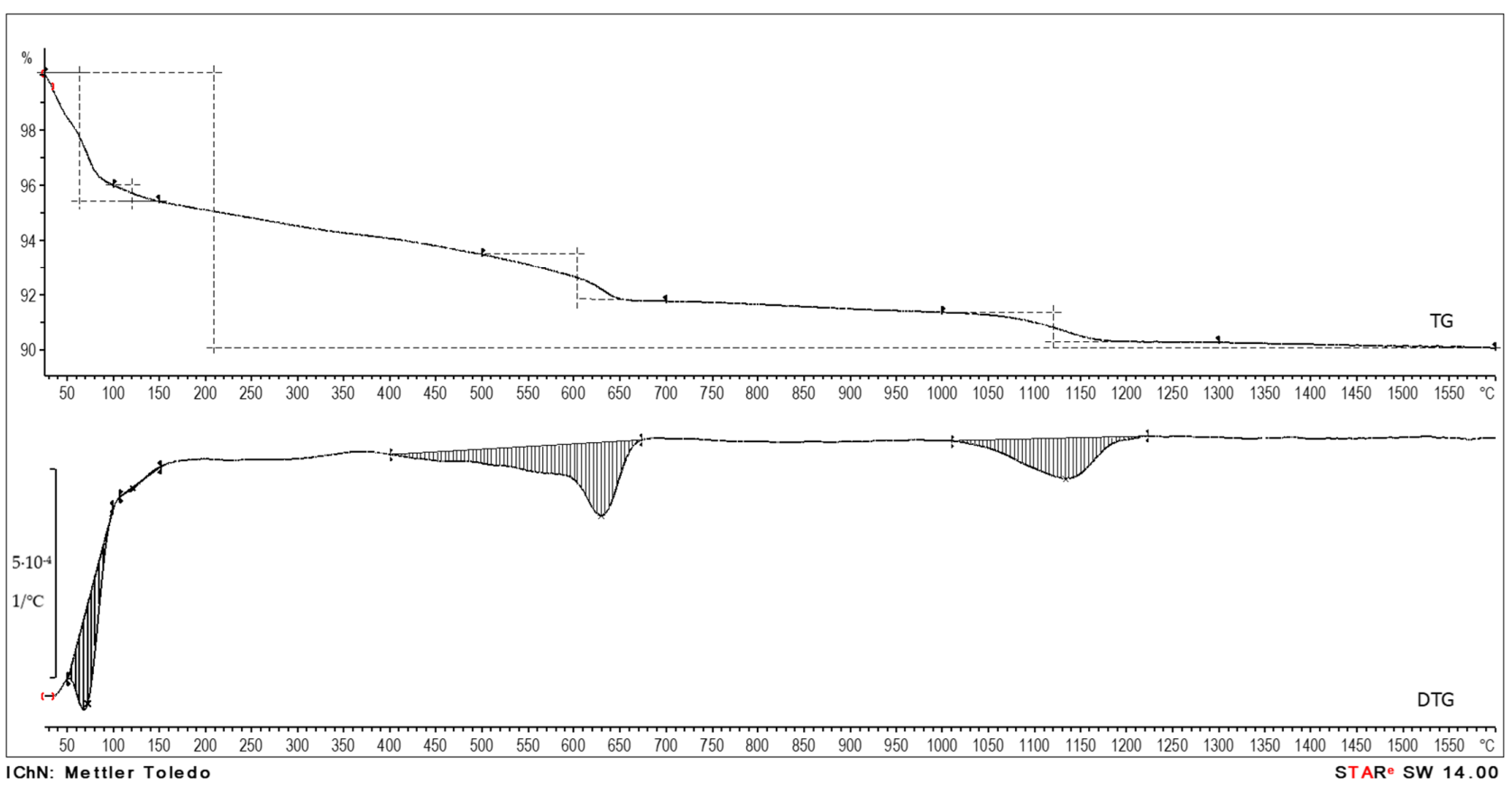

Figure 8. MSWIBA DTG.

Two small peaks related to the mass loss of the sample were observed. The mass loss in the temperature range $25-150{ }^{\circ} \mathrm{C}$ was $4.61 \%$. This was attributed to the evaporation of water and volatile organic solvents. The second thermal effect was in the range $500-700{ }^{\circ} \mathrm{C}$, with a peak maximum of $635.4^{\circ} \mathrm{C}$, which can probably be attributed to the thermal decomposition of organic substances. The mass loss in this range was $1.72 \%$, indicating little organic matter in the sample. The last energetic effect observed in the temperature range $1000-1300{ }^{\circ} \mathrm{C}$ was due to the decomposition of silicon or phosphorus compounds. The mass loss in this temperature range was $1.1 \%$, while the total mass loss for the studied sample $\left(25-1600{ }^{\circ} \mathrm{C}\right)$ was $9.9 \%$ [26].

\subsection{Glassy Phase}

The glassy phase content of construction material is a favorable characteristic, but not decisive for good hydraulic properties. The vitreous phase content affects the hydraulic activity of MSWIBA. Blast furnace slag, which is characterized by a high vitreous phase content, is used in the manufacture of types of cement and concretes.

The literature analysis showed that granulated blast furnace slags with a glassy phase content of 58-99\% meet the requirements of the PN-EN 15167-1:2007 standard [27].

The best hydraulic activity index had a blast furnace slag with 97-99\% glassy phase, with an activity coefficient $(\mathrm{CaO}+\mathrm{MgO}) / \mathrm{SiO}$ of about 1.3 [27].

An ingredient that exhibits hydraulic properties after appropriate activation and, in order to be used in cement, must meet the requirements of EN 197-1:2012 [N4.2], the most important of which are glassy phase content $\geq 67 \%, \mathrm{CaO}+\mathrm{MgO}+\mathrm{SiO}_{2}$ oxide sum content $\geq 67 \%$, and $\mathrm{CaO}+\mathrm{MgO} / \mathrm{SiO}_{2}$ mass ratio $\geq 1$ [27]. Figure 9 shows glassy phase of MSWIBA. 
00-020-0199; Ca2 Al2 Si 07; Gehlenite, syn; P-421m; Q: I;ALT

00-033-1161; Si O2; Quartz, syn; P3221; Q: S;ALT

00-066-0867; Ca ( C O3 ); Calcite; R-3c; Q: S

04-008-7638; Si O2; Cristobalite; P41212; Q: B;ALT

04-012-1764; Ca Si 03; Pseudowollastonite, syn; C2/c; Q: S

04-011-5267; Ca6 Al2 ( $\mathrm{S} \mathrm{O} 4$ )3 ( O H )12 ( $\mathrm{H} 2 \mathrm{O}$ )26; Ettringite; P31c; Q: B

00-031-0616; Fe2 Al4 Si5 018; Sekaninaite; Cccm; Q: I;ALT

01-088-0866; Fe3 O4; Magnetite; Fd-3m; Q: S;ALT

01-087-1166; Fe2 O3; Hematite; R-3C; Q: S;ALT

04-010-2581; Ca Si 03; Wollastonite-2M; P21/a; Q: S

00-009-0466; Na Al Si3 08; Albite, ordered; C-1; Q: S

04-008-1783; K Al Si3 08; Microcline; C-1; Q: I

01-075-8314; Si C; Moissanite-6H; P63mc; Q: S;ALT

10,000

04-014-7659; Fe2 ( $\mathrm{S} 04$ )2 O ( H2 O )8; Hohmannite; P-1; Q: B;ALT

0

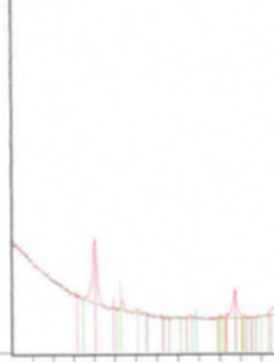

10

20

30

40

50

70

Position ["20] (Copper (Cu))

Figure 9. MSWIBA glassy phase.

Amorphous content of MSWIBA was about 71\%, which is not below the amorphous content of the average granulated blast furnace slag. Quartz was about $13 \%$. The content of calcite was $3.5 \%$ and content of $\mathrm{SiC}(6 \mathrm{H})$ was $3 \%$. Ettringite content was $0.6 \%$.

Based on the vitreous phase content, it was concluded that MSWIBA has hydraulic properties.

\subsection{Strength Tests}

The mortars included MSWIBA as 100\% fine aggregate substitute. Table 5 shows the 28-Day Compressive Strength of Mortar (MPa) with CEM I 42.5R and CSA.

Table 5. Strength tests: MSWIBA accounts for $100 \%$ by weight of aggregate.

\begin{tabular}{cccc}
\hline $\begin{array}{c}\text { Type of Cement } \\
\text { in Mortar }\end{array}$ & $\begin{array}{c}\text { Height of Mortar } \\
\text { Beam }(\mathbf{m m})\end{array}$ & $\begin{array}{c}\text { 28-Day Compressive } \\
\text { Strength of Mortar (MPa) }\end{array}$ & Standard Deviation \\
\hline CEM I 42.5 R & 42 & 26.98 & 0.75 \\
CSA & 42 & 40.23 & 3.21 \\
\hline
\end{tabular}

The beam strength with CSA was almost 1.5 times higher than with CEM I $42.5 \mathrm{R}$ The 28-Day Compressive Strength of CEM I 42.5 R mortar was $26.98 \mathrm{MPa}$, while CSA was $40.23 \mathrm{MPa}$.

CSA is a less-emissive cement; therefore, the use of MSWIBA along with CSA carries environmental benefits of reduced emissivity of the final product $[13,21,28]$.

\subsection{Leachability}

The leachability of MSWIBA contaminants into the environment is as important a parameter as the durability of the material. Which pollutants are used and their quantity are defined in the Ordinance of the Minister of Economy of 16 July 2015 on Allowing Waste 
to be Stored in Landfills. (Dz.u. Poz 1277) [29]. The amount of impurities in MSWIBA is presented in the work [8]. Table 6 shows the water extract pH of MSWIBA mortars with CEM I $42.5 \mathrm{R}$ and CSA.

Table 6. Water extract $\mathrm{pH}$ of MSWIBA mortars with CEM I $42.5 \mathrm{R}$ and CSA.

\begin{tabular}{ccc}
\hline Cement & CEM I 42.5 R & CSA \\
\hline $\mathrm{pH}$ & 11.96 & 10.39 \\
\hline
\end{tabular}

The $\mathrm{pH}$ of the water extract of the mortar with CEM I $42.5 \mathrm{R}$ is 11.96 , whereas the $\mathrm{pH}$ of the water extract with CSA is 10.39. Reinforcement corrosion occurs when the $\mathrm{pH}$ drops below 9.5. Freshly produced concrete has a $\mathrm{pH}$ of about 12.5. It follows that both mortars should have a slightly increased $\mathrm{pH}$, but this is not below the standard.

The solution to raising the $\mathrm{pH}$ of concrete may be to alkalinize MSWIBA before it is used in concrete. Not only will it raise the $\mathrm{pH}$, but it will also result in an improvement in the physicochemical properties of the material in terms of construction [25].

\section{Results Discussion}

MSWIBA is a heterogeneous material. However, MSWIBA is suitable as a substitute for aggregate. MSWIBA is not calorific, which was confirmed by the DTG analysis. MSWIBA meets the standards for aggregates for use in construction. Examination of the vitreous phase content [30] also confirmed the similarity to the materials used so far in the production of concrete, i.e., granular blast furnace slag. Moreover, based on the examination of the vitreous phase, it can be concluded that MSWIBA has the properties of SCMs. This is an additional advantage of MSWIBA when it is managed together with fly ash, which is produced in the same process of incineration of municipal waste. Fly ash is a hazardous waste and particularly difficult to recycle; therefore, the properties of MSWIBA will have a positive effect on the immobilization of pollutants.

Sieve analysis was carried out to select the correct fraction of aggregate for the concrete mix.The analysis showed that the next step is to select the correct amount of fine and coarse aggregate by methodical repetition. The resulting aggregate was compared with standard screening curves [31].

Cement production is a high-emission process; therefore, the research conducted a comparative analysis of two different cements-CSA and CEM I 42.5R. The production of CSA had less emissions, and the mortars using CSA had better mechanical properties. This translates into a reduction in the negative impact on the environment [32] in the production of a building mix with CSA and MSWIBA versus the usual building mix [33].

The $\mathrm{pH}$ of the water extract was suitable for both cements. CEM I $42.5 \mathrm{R}$ had a slightly better $\mathrm{pH}$. A suitably high $\mathrm{pH}$ affects the durability of the mixture. In further studies, $\mathrm{NaOH}$ pretretment may be used to increase the $\mathrm{pH}$ of the mixture. Then, MSWIBA is soaked in concentrated $\mathrm{NaOH}$, which additionally causes the immobilization of impurities and the improvement of physicochemical properties.

\section{Conclusions}

Rising global temperatures have a real impact on climate change. One effect is natural disasters, which translate into a human, environmental, and economic losses. To prevent global warming the European Commission has introduced the European Green Deal and the United Nations has introduced 17 Sustainable Developments Goals. The Community and the UN aim to introduce solutions to prevent environmental degradation and to help developing countries. One of the ideas is the circular economy, which aims to minimize waste and extend the life cycle of materials and products.

Not all waste can be recycled; therefore, inerting plants are an indispensable link in the waste management chain. These plants unfortunately produce secondary waste, which needs to be treated to close the loop. Waste-salaried plants produce the most bottom ash. 
One of the best environments for the immobilization of pollutants in the construction industry. In addition, construction is also one of the main global emitters of greenhouse gases into the environment and consumes significant amounts of natural resources. Secondary wastes have the potential to be substituted for natural raw materials and binders.

MSWIBA is considered to be an SCM that has hydraulic as well as pozzolanic properties. The use of MSWIBA will reduce greenhouse gas emissions, raw material extraction, and reduce landfill waste [34].

The study of the glassy phase confirms the potential for the use of MSWIBA in concrete. However, it is important to bear in mind the heterogeneity of the MSWIBA, which depends, among other things, on the municipal waste collection system and seasonality.

Studies conducted indicate that blocks with MSWIBA have better strength properties with CSA than with CEM I. By using CSA, the environmental impact is even lower than when using CEM I.

\section{Discussion}

The analysis of the literature indicates various studies on the development of MSWIBA in construction. This is, for example, an elemental and qualitative physicochemical analysis. Some items indicate MSWIBA pretreatment through the use of washing with water or alkali, e.g., $\mathrm{NaOH}$, and the influence of time, temperature, and concentration on the physicochemical properties and the immobilization of heavy metals.

The essence of this study was to investigate the selected fraction $(0-8 \mathrm{~mm})$ after valorization with the use of different types of cement and to compare their influence on the mechanical properties of the mortar. A relevant aspect of the work is also the comparison of CSA with CEM I 42.5R due to the lower emissivity of the CSA production. The research contributes to a better understanding of the material that is MSWIBA. Thanks to the tests of various fractions from different seasons, it is possible to better select material substitutes in concrete mixtures.

Further tests should include a full sieve analysis of the slag together with a supplementary aggregate mix. Such a mixture could form the basis for concrete testing.

The next research step could be to analyze both wastes, i.e., fly ash and MSWIBA. Such a combination will make it possible to take advantage of the slag's SCM characteristics, which will increase the immobilization of contaminants from the hazardous fly ash. Fly ash is the most burdensome waste from waste incineration plants, while it also has pozzolanic characteristics and therefore has potential for use in construction [35-37].

Another possibility would be the $\mathrm{NaOH}$ pretreatment of MSWIBA. NaOH pretreatment increases the immobilization of heavy metals and improves the physicochemical properties of MSWIBA. The alkaline treatment etches the material, thus increasing the strength of the mixture. The Figure 10 shows an example of MSWIBA treatment [9].

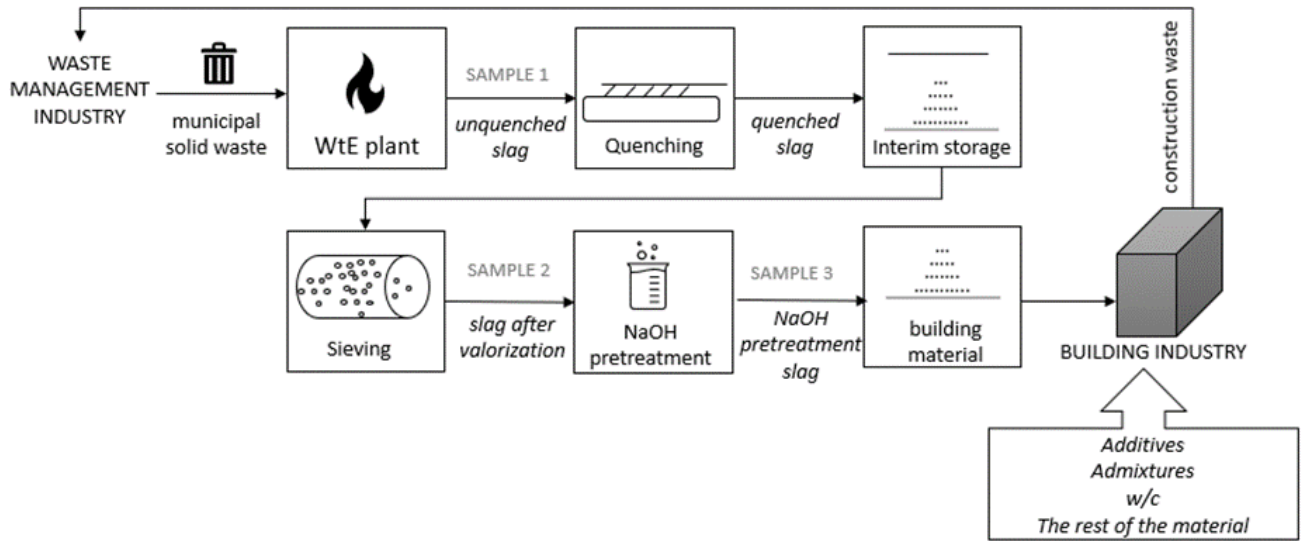

Figure 10. Example of MSWIBA processing. 
This treatment will generate liquid waste, which will also have to be managed. This will be another technological challenge, but the direction could be, for example, wastewater hygienization.

Author Contributions: Conceptualization, N.P. and B.Ł.-P.; methodology, B.Ł.-P., N.P. and A.C.; software, N.P. and A.C.; validation, N.P., A.C. and B.Ł.-P.; formal analysis, N.P.; investigation, B.Ł.-P. and N.P.; resources, B.E.-P. and K.P.; data curation, N.P. and A.C.; writing-original draft preparation, N.P.; writing-review and editing, B.t.-P.; visualization, N.P. and A.C.; supervision, B.E.-P. and K.P.; project administration, N.P. and K.P.; funding acquisition, N.P., K.P. and B.E.-P. All authors have read and agreed to the published version of the manuscript.

Funding: This research was funded by 08/030/BKM21/0094.

Conflicts of Interest: The authors declare no conflict of interest.

\section{References}

1. European Environment Agency. Cutting Greenhouse Gas Emissions through Circular Economy Actions in the Buildings Sector. Available online: https:/ / www.eea.europa.eu/themes/climate/cutting-greenhouse-gas-emissions-through/cutting-greenhousegas-emissions-through (accessed on 29 November 2021).

2. European Comission. Climate Action. Paris Agreement. Available online: https://ec.europa.eu/clima/eu-action/internationalaction-climate-change/climate-negotiations/paris-agreement_pl (accessed on 22 November 2021).

3. Deloitte. Raport: Closed Loop-Open Opportunities. Available online: https://www2.deloitte.com/pl/pl/pages/ zarzadzania-procesami-i-strategiczne/articles/innowacje/raport-zamkniety-obieg-otwarte-mozliwosci.html (accessed on 20 November 2021).

4. Climate of Risk. How Can Prevention and Insurance Reduce the Impact of Natural Disasters on the Environment? Deloitte; Ministry of the Environment: Warsaw, Poland, 2019; Available online: https:/ / piu.org.pl/wp-content/uploads/2021/03/raport-klimatycznyweb_eng.pdf (accessed on 23 December 2021).

5. A European Green Deal. European Commission. Available online: https://ec.europa.eu/info/strategy/priorities-2019-2024/ european-green-deal_en (accessed on 16 November 2021).

6. Wajd, A. Management of wastes from energy industry in the frame of circular economy on the example of microspheres. Sofia STEF92 Technol. 2018, 18. [CrossRef]

7. Lomborg, B. Impact of Current Climate Proposals. Glob. Policy 2015, 6, 109-118. [CrossRef]

8. Bogacka, M.; Poranek, N.; Łaźniewska-Piekarczyk, B.; Pikoń, K. Removal of Pollutants from Secondary Waste from an Incineration Plant: The Review of Methods. Energies 2020, 13, 6322. [CrossRef]

9. Xuan, D.; Poon, C.S. Removal of metallic $\mathrm{Al}$ and $\mathrm{Al} / \mathrm{Zn}$ alloys in MSWI bottom ash by alkaline treatment. J. Hazard. Mater. 2018, 344, 73-80. [CrossRef] [PubMed]

10. Wajda, A.; Jaworski, T. Research on the incineration processes of the solid waste in a rotary kiln. Sofia STEF92 Technol. 2019, 19, 367-374.

11. Wajda, A.; Jaworski, T. Optimization and Security of Hazardous Waste Incineration Plants with the Use of a Heuristic Algorithm. Sensors 2021, 21, 7247. [CrossRef] [PubMed]

12. Flower, D.J.M.; Sanjayan, J.G. Greenhouse gas emissions due to concrete manufacture. Int. J. Life Cycle Assess. 2007, 12, $282-288$. [CrossRef]

13. Benhelal, E.; Zahedi, G.; Shamsaei, E.; Bahadori, A. Global strategies and potentials to curb $\mathrm{CO}_{2}$ emissions in cement industry. J. Clean. Prod. 2013, 51, 142-161. [CrossRef]

14. Li, H.; Gao, P.; Xu, F.; Sun, T.; Zhou, Y.; Zhu, J.; Peng, C.; Lin, J. Effect of Fine Aggregate Particle Characteristics on Mechanical Properties of Fly Ash-Based Geopolymer Mortar. Minerals 2021, 11, 897. [CrossRef]

15. Barcelo, L.; Kline, J.; Walenta, G.; Gartner, E. Cement and carbon emissions. Mater. Struct. 2014, 47, 1055-1065. [CrossRef]

16. Pikoń, K.; Krawczyk, P.; Badyda, K.; Bogacka, M. Predictive Analysis of Waste Co-Combustion with Fossil Fuels Using the Life Cycle Assessment (LCA) Methodology. Energies 2019, 12, 3691. [CrossRef]

17. Keppert, M.; Pavlík, Z.; Černý, R.; Reiterman, P. Properties of Concrete with Municipal Solid Waste Incinerator Bottom Ash. Waste Manag. Res. J. Sustain. Circ. Econ. 2012, 30, 1041-1048. [CrossRef]

18. Li, H.; Zhang, H.; Yan, P.; Yan, C.; Tong, Y. Mechanical Properties of Furnace Slag and Coal Gangue Mixtures Stabilized by Cement and Fly Ash. Materials 2021, 14, 7103. [CrossRef]

19. Łagosz, A.; Tracz, T.; Mróz, R. Extending the Life Cycle of Cement Binders by Partially Replacing Portland Cement with Different Types Fluidized Bed Combustion Fly Ash. Minerals 2021, 11, 690. [CrossRef]

20. Hager, I.; Tracz, T.; Choińska, M.; Mróz, K. Effect of cement type on the mechanical behavior and permeability of concrete subjected to high temperatures. Materials 2019, 12, 3021. [CrossRef]

21. Feiz, R.; Ammenberg, J.; Baas, L.; Eklund, M.; Helgstrand, A.; Marshall, R. Improving the $\mathrm{CO}_{2}$ performance of cement, part I: Utilizing life-cycle assessment and key performance indicators to assess development within the cement industry. J. Clean. Prod. 2015, 98, 272-281. [CrossRef] 
22. Zimka, R.; Hajto, D.; Marcinkiewicz, K. CSA Cements based on calcium sulfoaluminates. Builder 2021, $20,80-82$.

23. Rojek, B. Termograwimetria i Spektroskopia w Podczerwieni Wspomagane Wielowymiarowymi Technikami Eksploracji Danych w Wykrywaniu Niezgodności Fizykochemicznych. Thermogravimetry and Infrared Spectroscopy Aided by Multidimensional Data Mining Techniques in Detecting Physicochemical Incompatibilities. Ph.D. Thesis, Gdańskiego Uniwersytetu Medycznego, Gdansk, Poland, 2014.

24. Pizoń, J.; Łaźniewska-Piekarczyk, B. Influence of curing conditions on long-term compressive strength of mortars. IOP Conf. Ser.-Mater. Sci. Eng. 2017, 245, 032093. [CrossRef]

25. Neville, A.M.; Brooks, J.J. Concrete Technology. Available online: https://books.google.com/books/about/Concrete_Technology $\mathrm{html}$ ?hl=pl\&id=GA2DngEACAAJ (accessed on 22 November 2021).

26. Kostova, B.; Petkova, V.; Kostov-Kytin, V.; Tzvetanova, Y.; Avdeevc, G. TG/DTG-DSC and high temperature in-situ XRD analysis of natural thaumasite. Thermochim. Acta 2021, 697, 178863. [CrossRef]

27. Baran, T.; Francuz, P.; Skawińska, A.; Tkocz, A. Kształtowanie właściwości cementów żużlowych z dodatkiem granulowanego żużla wielkopiecowego o różnej zawartości fazy szklistej. Molding properties of blast furnace slag cements with addition of granular blast furnace slag with different glassy phase content. Prace Instytutu Ceramiki i Materiałów Budowlanych. Work. Inst. Ceram. Build. Mater. 2017, 10, 7-19.

28. Giergiczny, Z.; Król, A.; Tałaj, M.; Wandoch, K. Performance of Concrete with Low $\mathrm{CO}_{2}$ Emission. Energies 2020, 13, 4328. [CrossRef]

29. Rozporzadzenie Ministra Środowiska z Dnia 18 Listopada 2014 r. w Sprawie Warunków, Jakie Należy Spełnić Przy Wprowadzaniu Ścieków do Wód Lub do Ziemi, Oraz w Sprawie Substancji Szczególnie Szkodliwych dla Środowiska Wodnego. (Ordinance of the Minister of Economy of 16 July 2015 on Allowing Waste to be Stored in Landfills). (Dz.u. Poz 1277). Available online: https:/ / isap.sejm.gov.pl/isap.nsf/DocDetails.xsp?id=WDU20140001800 (accessed on 24 November 2020).

30. Zevenbergen, C.; Wood, T.V.; Bradley, J.P.; van der Broeck, P.F.C.W.; Orbons, A.J.; van Reeuwijk, A.L.P. Morphological and Chemical Properties of MSWI Bottom Ash with Respect to the Glassy Constituents. Environ. Eng. Sci. 1994, 11, 371-383. [CrossRef]

31. Bilen, M.; Kizgut, S.; Akkaya, B. Prediction of unburned carbon in bottom ash in terms of moisture content and sieve analysis of coal. Fuel Process. Technol. 2015, 138, 236-242. [CrossRef]

32. Pizoń, J.; Gołaszewski, J.; Alwaeli, M.; Szwan, P. Properties of concrete with recycled concrete aggregate containing metallurgical sludge waste. Materials 2020, 13, 1448. [CrossRef]

33. Alwaeli, M.; Gołaszewski, J.; Niesler, M.; Pizoń, J.; Gołaszewska, M. Recycle option for metallurgical sludge waste as a partial replacement for natural sand in mortars containing CSA cement to save the environment and natural resources. J. Hazard. Mater. 2020, 398, 123101. [CrossRef]

34. Faleschini, F.; Toska, K.; Zanini, M.A.; Andreose, F.; Settimi, A.G.; Brunelli, K.; Pellegrino, C. Assessment of a Municipal Solid Waste Incinerator Bottom Ash as a Candidate Pozzolanic Material: Comparison of Test Methods. Sustainability 2021, $13,8998$. [CrossRef]

35. Garcia-Lodeiro, I.; Carcelen-Taboada, V.; Fernández-Jiménez, A.; Palomo, A. Manufacture of hybrid cements with fly ash and bottom ash from a municipal solid waste incinerator. Constr. Build. Mater. 2016, 105, 218-226. [CrossRef]

36. Lynn, C.J.; Ghataora, G.S.; Obe, R.K.D. Municipal incinerated bottom ash (MIBA) characteristics and potential for use in road pavements. Int. J. Pavement Res. Technol. 2017, 10, 179. [CrossRef]

37. Woo, B.-H.; Jeon, I.-K.; Yoo, D.-H.; Kim, S.-S.; Lee, J.-B.; Kim, H.-G. Utilization of Municipal Solid Waste Incineration Bottom Ash as Fine Aggregate of Cement Mortars. Sustainability 2021, 13, 8832. [CrossRef] 